\title{
Isolation and Characterization of Brachyspira spp. from Dogs in the Czech Republic
}

\author{
Daniel Šperling ${ }^{1}$, František Čada ${ }^{2}$, Alois Č́ížek ${ }^{1}$ \\ ${ }^{1}$ Department of Microbiology and Immunology, Faculty of Veterinary Medicine, University of Veterinary and \\ Pharmaceutical Sciences Brno, Czech Republic \\ ${ }^{2}$ Vedilab Analytika, Plzeň, Czech Republic \\ Received October 27, 2009 \\ Accepted March 8, 2010
}

\begin{abstract}
The objectives of this study were to establish the prevalence of intestinal Spirochetes of the genus Brachyspira in Czech dogs and to determine the susceptibility of obtained $B$. pilosicoli isolates to selected antibacterial substances. Spirochetes were diagnosed microscopically in 23 out of 1139 samples of dogs' excrements, primarily intended for a parasitological testing. The cultivation of positive samples provided 10 brachyspira isolates, which were, on the basis of their biochemical activity and the results of the species-specific PCR, identified as $B$. pilosicoli (9 isolates) and $B$. hyodysenteriae ( 1 isolate). These dogs came from households. All the 7 tested isolates $B$. pilosicoli were sensitive to metronidazole and doxycycline, uniformly resistant to erythromycin, partly sensitive to cefazoline, lincomicine and ampicilline except for one isolate of B. pilosicoli, which was resistant to ampicilline.

The second part of study was focused on dogs with diarrhoea that came from animal shelters, where a high prevalence of $58 \%(10 / 17)$ of $B$. pilosicoli was found.
\end{abstract}

Spirochetal colitis, susceptibility testing

In the past, spirochetes have been observed and isolated from colonic excrements and mucosa of both healthy dogs and dogs with diarrhoea. However, the pathogenic importance of spirochetes and their role in the onset of canine diarrhoea have not been sufficiently explained until now (Pindak et al. 1965; Turek and Meyer 1978; Meyer et al. 1982; Lee and Hampson 1994; Duhamel et al. 1995, 1997, 1998, Fellstrom et al. 2001; Oxberry and Hamps on 2003). Weakly haemolytic and indole-negative spirochetes colonising colon and rectum of healthy dogs were characterised by PCR method specific for 16S rRNA and MLEE (multilocus enzyme electrophoresis) and classified as a new species designated as „Brachyspira canis“. These spirochetes probably represent common canine intestinal commensals (Duhamel et al. 1998; Oxberry and Hampson 2003). Another species that has been isolated from canine and human faeces and the faeces of various animals in connection with diarrhoea and colonic infections is Brachyspira pilosicoli (Trott et al. 1996). This species tends to be detected in puppies with diarrhoea affected by a parasitic coinfection of Giardia spp. In adult dogs, it represents frequent finding also in the individuals without clinical symptoms (Turek and Meyer 1978; Duhamel et. al 1996). The cultures isolated from dogs were able to colonise chicken enterocytes via a mechanism similar to the one described in isolates of $B$. pilosicoli obtained from humans and pigs (Muniappa et al. 1996), which implies their pathogenic potential. Brachyspira pilosicoli is nowadays considered to be the causative agent of canine intestinal spirochetosis. Data on Brachyspira isolation from dogs came from studies on smaller groups of dogs or from sporadic cases of enteric infections documented more in detail (Oxberry and Hampson 2003; Skrzypcak et al. 2007). Reports on susceptibility of B. pilosicoli originating from dogs have appeared only rarely until now (Adachi et al. 2004).

The objective of this study was to establish the prevalence of intestinal spirochetes of

Address for correspondence:

MVDr. Daniel Šperling

Department of Microbiology and Immunology,

University of Veterinary and Pharmaceutical Science Brno,

Palackého 1-3, 61242 Brno, Czech Republic

Phone: +420724703583

E-mail: sperlingd@centrum.cz

http://www.vfu.cz/acta-vet/actavet.htm 
the genus Brachyspira in the population of individually bred dogs and those from animal shelters. Subsequently, the testing of sensitivity to antibiotics was performed for the selected isolates of B. pilosicoli.

\section{Materials and Methods}

Origin, sampling and analysis of faecal samples

A total of 1139 field canine faecal samples were obtained in the years 2006 and 2007 by the diagnostic service of Vedilab analytika, Plzeň. The dogs originated mainly from households at the central and western part of the Czech Republic and from the Prague urban area. The dogs' faeces were collected for parasitological testing which included lucid staining of the microscopic preparation with Victoria blue (Sigma-Aldrich, Czech Republic) (Kizerwetter-Swida et al. 2004). The samples positive for spirochetes were taken with a sterile swab and placed in a Amies Transport Medium (Oxoid, UK) and then sent to a diagnostic laboratory of the Institute of Microbiology and Immunology for cultivation. The primary isolation was performed on the selective Tryptose Soy Agar (BBL, USA) supplemented with 5\% citrated sheep blood and the antibiotic supplement composed of 5 antibiotics of the following final concentrations: rifampin $12.5 \mu \mathrm{g} / \mathrm{ml}$, spectinomycin $200 \mu \mathrm{g} / \mathrm{ml}$, colistin $6.25 \mu \mathrm{g} /$ $\mathrm{ml}$, vankomycin $6.25 \mu \mathrm{g} / \mathrm{ml}$ and cycloheximide $50 \mu \mathrm{g} / \mathrm{ml}$ (Kunkle et al. 1986; Dünser et al. 1997). Anaerobic cultivation ran for 7 days at $37^{\circ} \mathrm{C}$, in anaerobic jars at the atmosphere generated by the Gas generating kit (BR 038B, Oxoid) and the catalyst (BR 42, Oxoid). For the sub-cultivation of a culture of spirochetes, Wilkins Chalgren agar (Oxoid, UK) supplemented with 5\% citrated sheep blood was used. All the dishes were pre-dried before use and cuts were made by scalpel on the top of agar for easier isolation of bacterial culture (Olson et al. 1996). The type of haemolysis was always specified after 4 days of cultivation on the Tryptose Soy Agar with blood. Bacterial cultures were biochemically identified on the basis of sodium hippurate hydrolysis determination and hydrolytic activity of enzymes ( $\alpha$-glucosidase, $\beta$-glucosidase and $\alpha$-galactosidase) with the use of the diagnostic tablets (A/S Rosco, Denmark) (Fellström et al. 1995). The control strains of B. hyodysenteriae B78 (ATCC 27164 ${ }^{\mathrm{T}}$ ), B. pilosicoli (ATCC $51139^{\mathrm{T}}$ ) were used to control biochemical reactions.

Duplex PCR

The Duplex PCR protocol to detect B. pilosicoli and B. hyodysenteriae designed according to La et al. (2003) was used. The method is based on the amplification of the gene segment for NADH oxidase of B. hyodysenteriae and the amplification of the 16S rRNA gene segment of $B$. pilosicoli gene with the help of two pairs of specific primers. The following primer pairs were used during the reaction: H1 (5'ACTAAAGATCCTGATGTATTTG) and H2 (5'CTAATAAACGTCTGCTGC) for B. hyodysenteriae and P1 (5'AGAGGAAAGTTTTTTGGCTTC) and P2 (5'GCACCTATGTTAAACGTCCTTG) for B. pilosicoli. DNA extraction was performed by boiling with the use of an extractive TE buffer. Five-day-old bacterial cultures cultivated on Wilkins-Chalgren agar with sheep blood were used for the purpose of DNA extraction. The bacterial DNA extract at the volume of $2.5 \mu$ was added to the amplification mixture in a total volume of $25 \mu \mathrm{l}$, which was compounded from the buffer for PCR ( $1.5 \mathrm{mM}$ $\left.\mathrm{MgCl}_{2}\right), 0.5 \mathrm{U}$ HotStarTaq DNA Polymerase, $0.2 \mathrm{mM}$ of each NTP and from specific primer pairs (H1, H2 a P1, P2). The duplex-PCR itself proceeded in the following steps: after the initial 15 min activation of HotStarTaq Polymerase at $95{ }^{\circ} \mathrm{C}$, there were 30 cycles that consisted of denaturation under $94{ }^{\circ} \mathrm{C}$ for $30 \mathrm{~s}$, annealing at $52{ }^{\circ} \mathrm{C}$ for $30 \mathrm{~s}$ and extension at $72{ }^{\circ} \mathrm{C}$ for $1 \mathrm{~min}$. Visualisation of PCR products was performed on $1.5 \%$ agarose gel (Lachema, Czech Republic) in TBE buffer stained by ethidium bromide solution (Sigma) and the reading was carried out in UV transluminator. The distances of DNA products were compared with the standard (DNA marker 100-1000 bp, Bio-Rad Laboratories, Inc., USA).

Antimicrobial susceptibility testing

Susceptibility testing was routinely performed by dilution of antimicrobial agents on agar in accordance with the standard CLSI (formerly NCCLS- M11-A5) methods. For the needs of testing, Wilkins-Chalgren agar with $5 \%$ of sheep blood, pre-dried and with the appropriate concentration of the tested antibiotic was used. The solutions of tested antibiotics were prepared according to the instructions (NCCLS- M11-A5) and stored at $-20^{\circ} \mathrm{C}$ for 6 months. The media with antibiotics of various concentrations (dilution index 2 , the rank of the determined concentrations was lower) were prepared on the testing day. The antibiotics were tested at the following concentrations: erythromycin (Sigma), $200-0.36 \mathrm{mg} / \mathrm{ml}$; lincomycin (Pharmacia/Upjohn, UK), $128-0.25 \mathrm{mg} / \mathrm{ml}$; doxycycline (CEVA), 32-0.064 mg/ml; metronidazole (Sigma-Aldrich, Czech Republic), 16-0.032 mg/ml; ampicillin (Sigma-Aldrich, Czech Republic), $128-0.25 \mathrm{mg} / \mathrm{ml}$; cephazoline (Sigma-Aldrich, Czech Republic), $128-0.25 \mathrm{mg} / \mathrm{ml}$. Five-day-old culture of the B. pilosicoli isolates was suspended in saline and adjusted to the turbidity of McFarland standards 0.5 . The final concentration of bacterial cells was $3 \times 10^{6} \mathrm{CFU} / \mathrm{ml} ; 20 \mathrm{ml}$ of suspension was dropped on the agar surface in the form of a rosette. Thus there was a set of 5 tested isolates inoculated on each plate. The inoculum of each isolate on the agar surface reached the concentration of approximately $3 \times 10^{5} \mathrm{CFU} / \mathrm{ml}$. Wilkins-Chalgren anaerobic agar without antibiotics was used to control the growth. After 4 days of incubation at the temperature of $37^{\circ} \mathrm{C}$ in anaerobic jars, the minimal inhibitory concentration (MIC) for a given isolate was determined as the lowest concentration of an antibiotic which caused a total inhibition of growth and haemolytic activity of the bacterial culture. Each isolate was tested separately $3 \times$. The individual MIC values were classified and 
assessed on the basis of the interpretation criteria according to CLSI methods for anaerobic microorganisms and the given antimicrobial agent (NCCLS- M11-A5).

\section{Results}

Microscopic examination of fixed stained preparations revealed the presence of the spirochetes in $23(2 \%)$ out of 1139 canine faecal samples. Ten isolates of Brachyspira spp. were obtained by cultural examination of these samples. On the basis of evaluation of the haemolytic activity, phenotypic identification by the determination of glycosidase activity ( $\alpha$-galactosidase, $\beta$-glucosidase) and the subsequent specific identification by PCR, 9 isolates of spirochetes were identified as B. pilosicoli and 1 isolate was identified as $B$. hyodysenteriae. Three isolates of $B$. pilosicoli were biochemically atypical (galactosidase negative and $\beta$-glucosidase positive.), 6 isolates of $B$. pilosicoli were biochemically identified and consequently placed in the group IVa, characteristic for $B$. pilosicoli (Fellström et al. 1995). All the isolates of B. pilosicoli hydrolyzed sodium hippurate (Table 1).

Table 1. Identification of Brachyspire isolated form canine faecal samples complemented with other data

\begin{tabular}{|l|c|c|c|c|c|c|c|}
\hline $\begin{array}{l}\text { Isolate } \\
\text { number }\end{array}$ & Dog's age & $\begin{array}{c}\text { Giardia spp. } \\
\text { infestation }\end{array}$ & Haemolysis & $\alpha$-gal & $\beta$-glu & Na-hipp & Duplex PCR \\
\hline 2541 & puppy & - & weak & pos. & neg. & pos. & B. pilosicoli \\
\hline 2542 & 2.5 months & - & weak & pos. & neg. & pos. & B. pilosicoli \\
\hline 2543 & 2 months & ++++ & weak & neg. & pos. & pos. & B. pilosicoli \\
\hline 2548 & puppy & ++++ & weak & neg. & pos. & pos. & B. pilosicoli \\
\hline 2566 & unspecified & - & weak & neg. & pos. & pos. & B. pilosicoli \\
\hline 2571 & 3 months & ++++ & weak & pos. & neg. & pos. & B. pilosicoli \\
\hline 2579 & unspecified & ++++ & weak & pos. & neg. & pos. & B. pilosicoli \\
\hline 2585 & 1.5 months & + & weak & pos. & neg. & pos. & B. pilosicoli \\
\hline 2605 & unspecified & - & weak & pos. & neg. & pos. & B. pilosicoli \\
\hline 2697 & unspecified & - & full & dub. & dub. & neg. & B. hyodysenteriae \\
\hline
\end{tabular}

$\alpha$-gal - alpha galactosidase, $\beta$-glu - beta glucosidase, Na-hipp - sodium hippurate,

+- intensity of Giardia spp. infestation

All the isolates of B. pilosicoli obtained from the first sample set were uniformly resistant to erythromycin, sensitive to metronidazole and doxycycline, medium-sensitive to cefazolin, lincomycine and ampicillin, with the exception of one isolate of B. pilosicoli, which was resistant to ampicillin. The determined minimal inhibitory concentrations of the tested antibiotics for 7 selected isolates are presented in Table 2 .

A total number of 17 samples were taken from dogs of various age that came from animal

Table 2. Minimal inhibitory concentration of the selected antimicrobial substances for $B$. pilosicoli isolates originating from dogs

\begin{tabular}{|l|c|c|c|c|c|c|}
\hline Isolate number & AMP & CAF & DOX & MET & ERY & LIN \\
\hline 2542 & 16 & 2 & 0.125 & 0.125 & 256 & 1 \\
\hline 2543 & 1 & 2 & 0.125 & 0.125 & 512 & 4 \\
\hline 2548 & 1 & 2 & 0.125 & 0.125 & 512 & 4 \\
\hline 2566 & 1 & 2 & 0.125 & 0.125 & 512 & 4 \\
\hline 2579 & 1 & 2 & 0.06 & $<0.06$ & 256 & 2 \\
\hline 2585 & 2 & 2 & 0.06 & 0.125 & 128 & 2 \\
\hline 2605 & 1 & 2 & 0.06 & 0.125 & 128 & 2 \\
\hline
\end{tabular}

AMP - ampicillin, CAF - cefazolin, DOX - doxycycline, MET - metronidazole, ERY - erythromycin, LIN - lincomycine 
shelters. The dogs showed clinical symptoms of diarrhoea, 13 dogs were positive for the $\alpha$-haemolytic spirochetes after cultivation. The age of the tested animals was mostly under 2 years. Biochemical determination and PCR identified 10 isolates of B. pilosicoli and 3 isolates were not identified. Six dogs of the original set of 17 dogs were repeatedly tested after a week of treatment with a combination of amoxicillin and clavulanic acid and only one dog was positive for B. pilosicoli.

\section{Discussion}

We detected spirochetes in 23 (2\%) of 1139 dog using microscopic examination of faeces. The subsequent cultivation and identification revealed B. pilosicoli in 9 dogs and B. hyodysenteriae in one dog. The incidence of B. pilosicoli compared to other studies (Fellström et al. 2001; Oxberry et al. 2003) was lower, probably due to a larger group of dogs tested. Dogs of all age categories originated mostly from households in urban areas. Dogs were individually bred and kept in high-standard hygienic conditions. This fact may have influenced the final low prevalence of $B$. pilosicoli. More detailed data about individual dogs are not available. Diarrhoea caused by $B$. pilosicoli is more serious in puppies. Dogs positive for $B$. pilosicoli were puppies or young dogs under the age of 6 months.

One isolate of $B$. hyodysenteriae was isolated from a dog coming from an area with high density of pig farms with confirmed swine dysentery. This infected dog excretes $B$. hyodysenteriae and can serve as an occasional reservoir in pig breeding facilities.

The dogs were tested for the presence of intestinal parasites and in 5 dogs positive for B. pilosicoli, Giardia spp. was detected. It is not known whether the competitive parasitic infections work as the primary factor or if $B$. pilosicoli could be considered as the primary colonic pathogen. Competitive parasitic invasion can influence the intestinal function and probably has an impact on the course of the disease. In order to explain the role of $B$. pilosicoli it is necessary to conduct more detailed studies, especially those of experimental infections in puppies.

The results of the second part of study confirmed that puppies and young dogs kept in shelters are infected by Brachyspira spp. more frequently and suffer from diarrhoea. Higher positivity in young dogs is connected with lower immunity against infection inherited from mothers. Clinical manifestation of a disease occurs mainly in worse hygienic conditions and in larger groups, such as urban dog shelters and pet or animal shops (Koopman et al. 1993; Oxberry and Hampson 2003).

Brachyspira pilosicoli differs from other species of Brachyspira genus that have limited host spectrum and the ability to colonise several species of mammals and birds, including humans. Comparative studies characterizing $B$. pilosicoli isolates from various animal species including dogs and humans from various geographical areas indicate a possibility of interspecies transfer, especially between dogs and humans (Trott et al. 1998). Subtypization and comparison of isolates were performed using PFGE a MLEE methods (Trott et al. 1998; Hampson et al. 2006). The results indicated a characteristic loss of host specificity, colonisation of animals with human isolates and a probable zoonotic transfer, which can occur during contact with faeces of the infected dogs or by drinking contaminated water.

At present, there is little information about sensitivity of $B$. pilosicoli isolates from dogs to antibiotics. Adachi et al. (2004) determined MIC values for 14 antibiotics in 3 isolates of $B$. pilosicoli from Japanese dogs and they found that all isolates were sensitive to tested antibiotics with the exception of erythromycin and sedacamycin. In general, Brachyspira isolates from dogs are more sensitive to antimicrobial substances compared to the isolates from pigs (Adachi et al. 2004). The antibiotics we tested included the major groups of antibiotics used for treatment of canine enteric infections and in spirochetal infections in general. 
Resistance to erythromycin that belongs to macrolide antibiotic was determined in all isolates. This corresponds with the findings of resistance of porcine $B$. pilosicoli isolates (Karlss on et al.1999). This result is of clinical importance, because macrolide antibiotics are commonly recommended as second choice antibiotics suitable for the treatment of colonic infections in dogs.

One of the isolates was resistant to ampicillin. Ampicillin is the most widely used antibiotic in small animals and belongs to the first choice drugs for the therapy of colonic infections in small animals.

Some strains of $B$. pilosicoli isolated from pigs were resistant to antibiotic amoxicillin, which also belongs to aminopenicillins and susceptibility was subsequently re-established by adding clavulanic acid as inhibitor of beta-lactamases. Also some human isolates of $B$. pilosicoli showed beta-lactamase activity, and therefore the $B$. pilosicoli isolate we obtained can be presumed to also produce beta-lactamases (Brooke et al. 2003; Tompkins et al. 1987).

B. pilosili isolates were medium sensitive to lincomycine and cefazolin. High sensitivity of isolates was found to doxycycline and metronidazole that supports preferential selection of these drugs for the therapy of canine enteritis with Brachyspira aetiology.

Further research must be done to determine the aetiological importance of B. pilosicoli in canine diarrhoeal infections. Considering the wide host potential of this bacteria, there is a need to assess its zoonotic importance and determine the possible hazard to human health, especially in children that are in close contact with dogs.

\section{Izolace a identifikace intestinálních spirochét rodu Brachyspira spp. ze psů v České republice}

Cílem studie bylo stanovit prevalenci spirochét se zaměřením na původce spirochétové kolitis $B$. pilosicoli u českých psů a u získaných izolátů $B$. pilosicoli stanovit citlivost k vybraným antibiotickým látkám. V souboru 1139 vzorků trusu psů, jenž byly primárně určeny k parazitologickému vyšetření byla mikroskopií fixovaných barvených preparátů zjištěna ve 23 vzorcích prrítomnost spirochét. $Z$ těchto vzorků bylo kultivačním vyšetřením získáno 10 izolátů brachyspir, které byly na základě hodnocení biochemické aktivity a druhově specifické PCR identifikovány jako B. pilosicoli (9 izolátů) a B. hyodysenteriae (1 izolát). Všechny testované izoláty $B$. pilosicoli byly citlivé k metronidazolu a doxycyklinu. Izoláty B. pilosicoli ze psů byly uniformě rezistentní $\mathrm{k}$ erytromycinu, středně citlivé vůči ampicilinu, s výjimkou jednoho izolátu $B$. pilosicoli, který byl vůči ampicilinu rezistentní. Střední citlivost byla zaznamenána vůči cefazolinu a linkomycinu. Vysokou prevalenci B. pilosicoli se podařilo zjistit u psů s klinickou manifestací průjmového onemocnění umístěných v útulku pro opuštěná zvířata a to u 10 vyšetřených jedinců ze souboru 17 psů $(58 \%)$.

\section{Acknowledgment}

This work was partly supported by the Grant Agency of the Czech Republic, Grant No. 524/06/1501.

\section{References}

Adachi Y, Tasu C, Tanaka T, Kajiwara K, Tanaka T 2004: Brachyspira pilosicoli isolated from pigs and dogs in Japan and the susceptibility to 14 antibiotics. In Proceedings of the $18^{\text {th }}$ IPVS, Germany: p. 268

Brooke CJ, Hampson DJ, Riley TV 2003: In vitro antimicrobial susceptibility of Brachyspira pilosicoli isolates from humans. Ant Ag Chem 47: 2354-2357

CLSI 2003: Methods of antimicrobial susceptibility testing of anaerobic bacteria, Clinical and Laboratory Standards Institute. Document M11-A4. Edited by CLSI, Wayne, Pennsylvania

Duhamel GE, Elder RO, Muniappa N, Mathiensen MR, Wong VJ, Tarara RP 1997: Colonic spirochetal infections in nonhuman primates that were associated with Brachyspira aalborgi, Brachyspira pilosicoli, and unclassified flagellated bacteria. Clin Inf Dis 25: 186-188

Duhamel GE, Trott DJ, Muniappa N, Hampson DJ 1998: Canine intestinal spirochetosis consist of Serpulina pilosicoli and a newly identified group provisionally designated Serpulina canis sp. nov. J Clin Microbiol 36: 2264-2270 
Duhamel GE, Muniappa N, Mathiansen MR, Johnson JL, Toth J, Elder RO, Doster AR 1995: Certain canine weakly beta-hemolytic intestinal spirochetes are phenotypically and genotypically related to spirochetes associated with human and porcine intestinal spirochetosis. J Clin Microbiol 33: 2212-2215

Dunser M, Schweighardt H 1998: Antimicrobial susceptibility testing for Econor, Tiamutin and lincomycin against Serpulina hyodysenteriae and weakly beta-haemolytic intestinal spirochaetes. In Proc. IPVS 15th Congr. Birmingham: p. 140

Hampson DJ, Oxberry SL, La T 2006: Potencial for zoonotic transmission of Brachyspira pilosicoli. Em Inf Dis 12: $869-870$

Fellström C, Gunnarsson A 1995: Phenotypical characterisation of intestinal spirochaetes isolated from pigs. Res Vet Sci 59: 5-9

Fellström C, Pettersson B, Zimmerman U, Gunnarsson A, Fenstein R 2001: Classification of Brachyspira spp. isolated from Swedish dogs. Anim Health Res Rev 2: 75-82

Karlsson M, Fellström C, Heldtander MU, Johansson KE, Franklin A 1999: Genetic basis of macrolide and lincosamide resistance in Brachyspira (Serpulina) hyodysenteriae. FEMS Microbiol Lett 172: 255-260

Kizerwetter-Swida M, Rzewurska M, Binek M 2005: Characterization of Brachyspira spp. strains isolated from flock of hens with diarrhoea. Bull Vet Inst Pulawy 49: 169-173

Koopman MBH, Käsbohrer A, Beckmann G, Van der Zeijst BAM, Kusters JG 1993: Genetic similarity of intestinal spirochetes from humans and various animal species. J Clin Microbiol 31: 711-716

Kunkle RA, Kinyon JM 1988: Improved selective medium for the isolation of Treponema hyodysenteriae. J Clin Microbiol 26: 2357-2360

La T, Phillips ND, Hampson DJ 2003: Development of a Duplex PCR assay for the detection Brachyspira hyodysenteriae and Brachyspira pilosicoli in pig faeces. J Clin Microbiol 41: 3372-3375

Lee JI, Hampson DJ 1994: Genetic characterisation of intestinal spirochaetes and their association with disease. J Med Microbiol 40: 365-371

Meier CD, Srisopar B, Amtsberg G 1982: Untersuchungen zur Vorkommen von Treponemen bei Hunden mit Darmerkrankungen. Berl Münch Tierärztl Wochenschr 95: 185-188

Muniappa N, Duhamel GE, Mathiesen MR, Bargar TW 1996: Light microscopic and ultrastructural changes in the ceca of chicks inoculated with human and canine Serpulina pilosicoli. Vet Phatol 33: 542-550

Olson LD 1996: Enhanced isolation of Serpulina hyodysenteriae by using sliced agar media. J Clin Microbiol 32: 2937-2941

Oxberry SL, Hampson DJ 2003: Colonisation of pet shop puppies with Brachyspira pilosicoli. Vet Microbiol 93: 167-174

Pindak F, Clapper WE, Sherrod JH 1965: Incidence and distribution of spirochetes in the digestive tract of dogs. Am J Vet Res 26: 1391-1402

Skrzypczak T, Fossi M, Ahola H, Vuorela J, Prusti M 2007: Occurrence of Brachyspira spp. In farmed birds and dogs in Finland- a preliminary study. In the Proceedings of $4^{\text {th }}$ Congress Intestinal Colonic Spirochaetal Infection in Animals and Humans, Prague, Czech Republic: p. 40

Trott DJ, Huxtable CR, Hampson DJ 1996: Experimental infection of newly weaned pigs with human and porcine strains of Serpulina pilosicoli. Inf Immun 64: 4648-4654

Tompkins DS, Millar MR, Heritage J, West AP 1987: Beta-lactamase production by intestinal spirochaetes. J Gen Microbiol 133: 761-765

Turek JJ, Meyer RC 1977: Studies on a canine intestinal spirochete: Its isolation, cultivation and ultrastructure. Can J Comp Med 41: 332-337 